\title{
Study of vitamin D deficiency and supplementation in pre-eclamptic toxemia \& its feto-maternal outcome
}

\author{
Neetu Singh ${ }^{1 *}$, Dileep kumar ${ }^{2}$, Kiran Pandey ${ }^{1}$, Neena Gupta ${ }^{1}$, Rashmi Balyan ${ }^{1}$, Ani Chandanan ${ }^{1}$
}

${ }^{1}$ Department of Obstetrics \& Gynaecology, GSVM Medical College, Kanpur, UP, India

${ }^{2}$ DPMR (RALC), KGMU, Lucknow, UP, India

Received: 04 September 2015

Revised: 17 October 2015

Accepted: 21 October 2015

\section{*Correspondence:}

Dr. Neetu Singh,

E-mail: drneetusingh73@gmail.com

Copyright: () the author(s), publisher and licensee Medip Academy. This is an open-access article distributed under the terms of the Creative Commons Attribution Non-Commercial License, which permits unrestricted non-commercial use, distribution, and reproduction in any medium, provided the original work is properly cited.

\section{ABSTRACT}

Background: The present study has been conducted to study the prevalence of vitamin D deficiency and evaluate the efficacy of vitamin D supplementation over pre-eclamptic women \& its maternal and neonatal outcome.

Methods: The present study was conducted on 280 pre-eclamptic women. In $2^{\text {nd }} \& 3^{\text {rd }}$ trimester attending outpatient department at Upper India Sugar Exchange Maternity Hospital, Department of Obstetrics and Gynecology G.S.V.M. Medical college, Kanpur, during the period of January 2013 to July 2014.Vit D measured on first visit and supplementation of vitamin D 2000 IU per day accordingly .Patients were followed till delivery for antinatal and neonatal outcome.

Results: Vitamin D supplementation had significant reduction in incidence of severe preeclampsia. Vitamin D supplementation had significant 1.4 times reduction in incidence of caesarian section $(\mathrm{OR}=3.659,95 \% \mathrm{CI}=1.3668$ to 9.9745, $\mathrm{P}=0.01$ ). Only $7.141 \%$ who received Vitamin D supplementation had new born with birth weight $>2.5 \mathrm{~kg}$ in comparison to $26.67 \%$ pregnant women who did not received Vitamin D supplementation $(\mathrm{OR}=4.8431,95 \%$ $\mathrm{CI}=1.6928-13.8561, \mathrm{P}=0.0033)$.

Conclusions: Vitamin D supplementation is significantly associated with better maternal and neonatal outcome.

Keywords: Pre-eclampsia, Caesarian-section, Eclampsia

\section{INTRODUCTION}

Preeclampsia is a pregnancy specific disorder that can affect virtually every organ system. Pathogenesis of preeclampsia involve a number of biological processes that may be directly or indirectly affected by Vitamin D include immune dysfunction; placental implantation, abnormal angiogenesis excessive inflammation and hypertension, genetic factors. ${ }^{1}$

Furthermore abnormal implantation is proposed to be mediated at least in part by an appropriate immune response between mother and baby the immunomodulatory properties of 1,25 dihydroxy Vitamin D3 may be relevant in the regard. ${ }^{2}$
The relationship between low Vitamin D and adverse maternal outcomes such as pregnancy - induced hypertension, recurrent pregnancy loss, preterm delivery, and primary Caesarian section has been documented in recent years.

Though Vitamin D comes from both diet and sunlight, food is a poor source of Vitamin D. Concern regarding association of sunlight with skin cancer and with aging has discouraged people from exposing to Sun. Dark skin, multiparty, short spacing between pregnancies, vegetarianism, crowding and purdah system (in muslims) further compound it. Deficiency of Vitamin D is widespread in India. Public health need to fortify Indian foods with Vitamin D has been suggested. 
The Institute of Medicine(2011) recommendation suggest a normal level of $20 \mathrm{ng} / \mathrm{ml}$ in pregnancy, while the Endocrine Society(2011) recommends $30 \mathrm{ng} / \mathrm{ml}$ or more suggest that pregnant women should have a circulating vitamin-D>40 $\mathrm{ng} / \mathrm{ml}$, irrespective of how it is achieved.

Maternal vitamin D supplementation in second trimester is significantly associated with better maternal and neonatal outcome.

There is evidence that 1000-2000 IU/per day of vitamin$\mathrm{D}$ is safe (American College of Obstetricians and Gynaecologists, 2011, Grant et al 2014, endocrine society). In antenatal women 1000-2000 IU/per day can be supplemented daily in the second and the third trimesters without fear of vitamin-D toxicity or teratogenicity. No safety data however, is available for the first trimester with this dose.

This study proposed to evaluate the effect of Vitamin D supplementation to pregnant women. The effect has been evaluated on the frequency of complications of pregnancy, on the parameters of Vitamin D sufficiency in the mother at term, on mode of delivery and health of the newborn.

Results of this study may provide insight as to whether or not Vitamin D supplementation in pregnant women could prevent adverse outcome for the mother as well as fetus

\section{METHODS}

The cases were randomly allocated. Subjects were classified in two Groups:

$\checkmark$ Study Group A included subject who received Vitamin D supplementation (2,000IU/day) along with conventional antenatal care.

$\checkmark$ Study Group B included subject who received conventional antenatal care only but did not received Vitamin D supplementation.

$\checkmark$ Control Group included subject who received conventional antenatal care only but did not received Vitamin D supplementation.

Vitamin D-25 $\mathrm{OH}$ in $\mathrm{ng} / \mathrm{ml}$ was measured in first visit. Woman with Vitamin D-25 $(\mathrm{OH})>30 \mathrm{ng} / \mathrm{ml}$ required to further testing or follow up. Woman with Vitamin D-25 $(\mathrm{OH})<30 \mathrm{ng} / \mathrm{ml}$ recommended Vitamin- D 2000 IU per day. Both Groups were followed till delivery.

\section{Inclusion criteria}

Women who have agreed to participate in the study and ready to receive Vitamin $\mathrm{D}$.

\section{Exclusion criteria}

Patients with chronic hypertension, hypercalcemia or family history of parathyroid disorder, liver or kidney disease active tuberculosis, sarcoidosis, lymphoma and other granulomatous disease, drugs known to alter Vitamin D metabolism were excluded from the study.

\section{RESULTS}

Table 1: Demographic profile.

\begin{tabular}{|lll|}
\hline & Study Group & $\begin{array}{l}\text { Control } \\
\text { Group }\end{array}$ \\
\hline Mean age \pm SD & $27.7 \pm 3.95$ & $27.9 \pm 2.78$ \\
\hline $\begin{array}{l}\text { Gestational age } \pm \\
\text { SD }\end{array}$ & $26.3 \pm 2.85$ & $27.9 \pm 3.99$ \\
\hline Parity & & \\
\hline $\mathrm{P}_{1}$ & $75.71 \%$ & $72.86 \%$ \\
\hline $\mathrm{P}_{2}$ & $17.14 \%$ & $15.71 \%$ \\
\hline $\mathrm{P}_{3}$ & $7.15 \%$ & $11.43 \%$ \\
\hline $\begin{array}{l}\text { Low } \\
\text { Socioeconomic } \\
\text { status }\end{array}$ & $67.14 \%$ & $58.57 \%$ \\
\hline
\end{tabular}

Table 2: Distribution of cases according to level of vitamin d-25 (oh) in maternal serum.

\begin{tabular}{|lllll|}
\hline VIT.D $((\mathbf{n g} / \mathrm{ml})$ & $\begin{array}{l}\text { Study Group } \\
(\mathrm{n=140})\end{array}$ & \multicolumn{2}{l|}{$\begin{array}{l}\text { Control } \\
\text { Group } \\
(\mathbf{n = 1 4 0})\end{array}$} \\
\hline TABLE & No. & $\%$ & No. & $\%$ \\
\hline$<30-40$ & 2 & 1.43 & 126 & 90.00 \\
\hline $20-30$ & 50 & 35.71 & 10 & 7.14 \\
\hline $10-20$ & 84 & 60.00 & 2 & 1.43 \\
\hline$<10$ & 4 & 2.86 & 2 & 1.43 \\
\hline $\mathrm{t}=21.19 ; \mathrm{p}<0.0001$ & & & & \\
\hline
\end{tabular}

Table 3: Distribution of cases according to mode of delivery.

\begin{tabular}{|c|c|c|c|c|}
\hline \multirow[t]{2}{*}{$\begin{array}{l}\text { Mode of } \\
\text { delivery }\end{array}$} & \multicolumn{2}{|c|}{$\begin{array}{l}\text { Study group A } \\
(\mathrm{n}=70)\end{array}$} & \multicolumn{2}{|c|}{$\begin{array}{l}\text { Study group B } \\
\text { (Control) } \\
(\mathrm{n}=70)\end{array}$} \\
\hline & No. & $\%$ & No & $\%$ \\
\hline Vaginal & 64 & 91.43 & 52 & 72.86 \\
\hline $\begin{array}{l}\text { Instrumental } \\
\text { delivery }\end{array}$ & \multirow[t]{2}{*}{1} & \multirow[t]{2}{*}{1.42} & \multirow[t]{2}{*}{16} & \multirow[t]{2}{*}{22.82} \\
\hline Forceps & & & & \\
\hline Ventouse & 2 & 2.85 & 1 & 1.41 \\
\hline Caesarean & 6 & 8.57 & 1 & 1.41 \\
\hline Total & 70 & 100 & 70 & 100 \\
\hline
\end{tabular}

Maximum no. of patients in study was found in 25-29 yrs of age Group. Mean gestational age in study Group is 27.7 \pm 3.95 . Mean gestational age in control Group is $27.9 \pm 2.78$ (Table 1). Majority of patients in the study were primigravida, $75 \%$ among study Group and $72.86 \%$ among control Group (Table 1). Majority of patients in present study belonged to low socio economic strata (Table 1). Table 2 shows that level of vitamin D-25 $(\mathrm{OH})$ in maternal serum in both Groups. In study Group 
mean vitamin D-25 $(\mathrm{OH})$ level of maternal serum was $18.13 \pm 6.4 \mathrm{ng} / \mathrm{ml}$ and in control Group was $32.35 \pm 4.63 \mathrm{ng} / \mathrm{ml}$. Thus mean vitamin D-25 $(\mathrm{OH})$ level of maternal serum in control Group is significantly higher than study Group $[\mathrm{P}<0.0001]$. Results in our study showed that on comparison of mode of delivery after vitamin D supplementation, there was a significant reduction in incidence of caesarean section, as in comparison to $18(29.14 \%)$ patients among study Group B only 6 patients $(8.57 \%)$ among study Group were delivered by caesarean section (Table 3). In study Group A $1.42 \%$ patient was delivered by forceps and $2.85 \%$ patients were delivered by ventouse. In study Group B $22.82 \%$ patients were delivered by forceps and $1.42 \%$ patient is delivered by ventouse. In our study showed that Vitamin-D supplementation were associated with decreased rate of maternal morbidity. In study Group A morbidity were severe preeclamptic toxaemia $1.43 \%$, gestational diabetes in $1.43 \%$, preterm labour in $2.86 \%$, bacterial vaginosis in $1.43 \%$, HELLP syndrome in $1.43 \%$ and ARF in $1.43 \%$, DIC in $1.43 \%$. In our study showed that maternal morbidity in both Groups. In study Group B morbidity was severe preeclamptic toxaemia in. $24.29 \%$, gestational diabetes in $5.71 \%$ preterm labour in $7.14 \%$, HELLP syndrome in $4.29 \%$, bacterial vaginosis in $4.29 \%$, ARF in $2.85 \%$, DIC in $1.43 \%$. Thus VitaminD supplementation was associated with decreased rate of maternal and neonatal morbidity. Morbidity in study Group A due to lack of follow up visit \& improper intake of drug (Table 4). Table 5 shows that level of vitamin $\mathrm{D}-25(\mathrm{OH})$ in cord blood in both Groups. In study Group A mean vitamin D-25 $(\mathrm{OH})$ level of cord blood was $32.71 \pm 4.9494 \mathrm{ng} / \mathrm{ml}$. and in study Group B was $27.38 \pm 5.04 \mathrm{ng} / \mathrm{ml}$. Thus mean vitamin D-25 $(\mathrm{OH})$ level of cord blood in study Group is significantly higher than control Group $[\mathrm{P}<0.0001]$.

In study Group A morbidity were Preterm birth in 7.14\%, and low APGAR score in $7.14 \%$, DIC in 1.43 , In study Group B morbidity were Preterm birth in $26.67 \% . \%$, and low APGAR score in $30 \%$, DIC in 1.43 (Table 6).

\section{DISCUSSION}

In the past few years a growing interest in Vitamin D has been observed in the biomedical literature due to findings demonstrating a low Vitamin D in population and its association with multiple disorders.

The present study has been conducted to study the prevalence of Vitamin D deficiency and evaluate the efficacy of vitamin D supplementation over maternal complications and neonatal outcome.

The study was carried out on 280 patients from Jan 2013 to July 2014 in department of obstetrics \& Gynecology GSVM Medical College Kanpur In our study showed that majority of patients were in age Group 25-29 yrs. Mean gestational age in study Group A was 27.7 \pm 3.95 . Mean gestational age in study Group B was 27.9 \pm 2.78 and majority were found to be primigravida, $75.7 \%$ among study Group and $72.86 \%$ among controls. Majority of patients belonged to lower socioeconomic status. The study shows that level of vitamin D-25 $(\mathrm{OH})$ in maternal serum in both Groups. In study Group mean vitamin D$25(\mathrm{OH})$ level of maternal serum was $18.13 \pm 6.4 \mathrm{ng} / \mathrm{ml}$ and in control Group was $32.35 \pm 4.63 \mathrm{ng} / \mathrm{ml}$. Thus mean vitamin D-25 $(\mathrm{OH})$ level of maternal serum in control Group is significantly higher than study Group $[\mathrm{P}<0.0001]$.

Table 4: Improvement in maternal outcome after treatment.

\begin{tabular}{|lllll|}
\hline & \multicolumn{2}{l}{$\begin{array}{l}\text { Study group-A } \\
(\mathrm{n=70})\end{array}$} & \multicolumn{2}{l|}{$\begin{array}{l}\text { Study } \\
\text { group-B } \\
(\mathrm{n=70})\end{array}$} \\
& No. & $\%$ & No & $\%$ \\
\hline $\begin{array}{l}\text { Severe } \\
\text { preeclamptic } \\
\text { toxaemia }\end{array}$ & 1 & 1.43 & 17 & 24.29 \\
\hline $\begin{array}{l}\text { Gestational } \\
\text { Diabetes }\end{array}$ & 1 & 1.43 & 4 & 5.71 \\
\hline Preterm Labour & 2 & 2.86 & 5 & 7.14 \\
\hline $\begin{array}{l}\text { Bacterial } \\
\text { Vagionosis }\end{array}$ & 1 & 1.43 & 3 & 4.29 \\
\hline HELLP syndrome & 1 & 1.43 & 3 & 4.29 \\
\hline ARF & 1 & 1.43 & 2 & 2.85 \\
\hline DIC & 1 & 1.43 & 3 & 4.29 \\
\hline
\end{tabular}

Table 5: Distribution of cases according to level of serum vitamin D-25 (oh) in cord blood.

\begin{tabular}{|lllll|}
\hline $\begin{array}{l}\text { S. Vitamin D } \\
(\mathrm{ng} / \mathrm{ml})\end{array}$ & $\begin{array}{l}\text { Study group A } \\
(\mathrm{n}=70)\end{array}$ & $\begin{array}{l}\text { Study group } \\
\text { B (Control) } \\
(\mathrm{n}=70)\end{array}$ \\
\hline$<30-40$ & No. & $\%$ & No. & $\%$ \\
\hline $20-30$ & 4 & 52.86 & 26 & 37.14 \\
\hline$<20$ & 1 & 1.42 & 2 & 2.86 \\
\hline $\mathrm{t}=6.465 ; \mathrm{p}<0.0001$ & & & \\
\hline
\end{tabular}

Table 6: Improvement in neonatal outcome after treatment.

\begin{tabular}{|lllll|}
\hline & \multicolumn{3}{l}{$\begin{array}{l}\text { Study group-A } \\
(\mathrm{n}=70)\end{array}$} & $\begin{array}{l}\text { Study group- } \\
\text { B } \\
(\mathrm{n}=70)\end{array}$ \\
& No. & $\%$ & No & $\%$ \\
\hline Apgar store $<7$ & 5 & 7.14 & 17 & 24.29 \\
\hline $\begin{array}{l}\text { Birth weight } \\
<2.5 \mathrm{~kg}\end{array}$ & 5 & 7.14 & 19 & 27.74 \\
\hline
\end{tabular}

In study Group A morbidity were severe preeclamptic toxaemia $1.43 \%$, gestational diabetes in $1.43 \%$, preterm labour in $2.86 \%$, bacterial vaginosis in $1.43 \%$, HELLP syndrome in $1.43 \%$ and ARF in $1.43 \%$, DIC in $1.43 \%$. In our study showed that maternal morbidity in both 
Groups. In study Group B morbidity were severe preeclamptic toxaemia in $24.29 \%$, gestational diabetes in $5.71 \%$ preterm labour in $7.14 \% \%$, HELLP syndrome in $4.29 \%$, bacterial vaginosis in $4.29 \%$, ARF in $2.85 \%$, DIC in $1.43 \%$ Thus Vitamin-D supplementation were associated with decreased rate of maternal and neonatal morbidity. Morbidity in study Group A due to lack of follow up visit \& improper intake of drug.

Similar to our result Lisa M. bodnar et al reported that vitamin-D supplementation decrease the chance of developing severe preeclampsia. ${ }^{3}$

Results in our study showed that on comparison of mode of delivery after vitamin D supplementation; there was a significant reduction in incidence of caesarean section, as in comparison to $18(29.14 \%)$ patients among study Group B (control) only 6 patients $(8.57 \%$ ) among study Group A were delivered by caesarean section.).In study Group A $1.42 \%$ patient was delivered by forceps and $2.85 \%$ patients were delivered by ventouse. In study Group B 22.42\%patients were delivered by forceps and $1.41 \%$ patient is delivered by ventouse. To analyse this association logistic regression analysis was applied with two Groups - control \& study consisted the independent variable and a logit model was fitted to relate the probability of mode of delivery as dependent variable. The Model fit is statistically significant $(p=0.0061)$. This relationship was also found to be statistically significant $(\mathrm{P}=0.01)$. Odds ratio has been found to be $3.69(95 \%$ $\mathrm{CI}=1.3668$ to 9.9745$)$. This implies that after receiving vitamin D supplementation there is almost 1.4 times reduction in incidence of caesarean section.

Our results are also consistent with the study conducted by Dr. Anne Merewood et al, which concluded that there is an inverse association with having a caesarean section \& S.25 (OH) D levels. ${ }^{9}$ They found that $28 \%$ of women with vitamin D level $<37.5 \mathrm{nmol} / 1$ had caesarean section compared with only $14 \%$ of women with vitamin D level $37.5 \mathrm{nmo1} / 1$ or greater.

In our study level of vitamin D-25(OH) in cord blood in both Groups. In study Group A mean vitamin D-25 $(\mathrm{OH})$ level of cord blood was $32.71 \pm 4.9494 \mathrm{ng} / \mathrm{ml}$. In study Group B (control) mean vitamin D level of cord blood was $27.38 \pm 5.04 \mathrm{ng} / \mathrm{ml}$. Thus mean vitamin D-25 $(\mathrm{OH})$ level of cord blood in study Group is significantly higher than study Group B (control) $[\mathrm{P}<0.0001]$.

Our result shows that neonatal Vitamin D status at birth is highly correlated with maternal Vitamin storage. These results correlate with other studies also.

Rochat MK et al found that mother supplemented with Vitamin D showed $25(\mathrm{OH}) \mathrm{D}$ value in cord blood higher than mother who was not supplemented with vitamin D. ${ }^{5}$

Our study showed that women who received vitamin D supplementation had a significant improvement in birth weight of newborns, as only $7.14 \%$ women in study Group A had newborns with birth weight $<2.5 \mathrm{~kg}$ in comparison to $26.67 \%$ among study Group B (control). These findings were also statistically significant $(\mathrm{P}=0.0013)$. To analyse the association of vitamin $\mathrm{D}$ supplementation with neonatal birth weight logistic regression analysis was applied with two Groups - control \& study consisted the independent variable and a logit model was fitted to relate the probability of Birth weight as dependent variable. The Model fit is statistically significant $(p=0.0061)$. Regression coefficient (1.57) in case of study Group A, who received vitamin D is also statistically highly significant $(\mathrm{P}=0.0033)$. Odds ratio has been found to be 4.8431 (95\% $\mathrm{CI}=1.6928$ to 13.8567 ). This implies that there are 1.6 time more chances of having birth weight $>2.5 \mathrm{~kg}$ with vitamin $\mathrm{D}$.

Hence our findings suggest that adequate consumption of vitamin $\mathrm{D}$ during pregnancy may promote a better birth weight.

Similar to our results, Scholl TO et al (2009) reported that vitamin D supplementation lowered the incidence of low birth weight. ${ }^{6}$

Our study showed that vitamin D supplementation has produced better APGAR score as in comparison to $30 \%$ among study Group B (control) only $7.14 \%$ mothers in study Group A had newborns with APGAR score $<7$. For a better study APGAR was categorized into normal (>7) and less than normal (i.e. <7) Groups and logistic regression analysis was applied to assess its association with two Groups - control \& study consisted the independent variable and a logit model was fitted to relate the probability of APGAR as dependent variable. The Model fit is statistically significant $(p=0.0003)$ Regression coefficient in case of vitamin D supplementation (1.7) is also statistically highly significant $(\mathrm{P}=0.0013)$. Odds ratio is found to be 5.5714 (95\% $\mathrm{CI}=1.9625$ to 15.8170$)$. This implies that there are 1.9 times more chances of having better APGAR score after vitamin D supplementation.

In concordance to our results study by Sabour $\mathrm{H}$ et al also concluded that APGAR score at birth was higher in newborns of mothers with adequate Vitamin D intake than newborn whose mothers had inadequate intake. ${ }^{7}$

\section{Compliance, adverse effects and safety regarding high dose of Vitamin D}

Results in our study showed beneficial effects of oral dose of Vitamin D during pregnancy over normal routine antenatal supplementation.

In our study, treatment was very well tolerated and simple dosing regimen allowed convenient outpatient management. No subject has shown symptoms of vitamin D toxicity (nausea, vomiting, joint pain, and tingling sensation in mouth). None of them have shown 
serum Calcium levels above the upper limit and there was no evidence of renal impairment as shown by normal serum Creatinine throughout study in all participants.

\section{CONCLUSION}

Vitamin D deficiency is common during pregnancy especially among high risk Group. This study supports a recommendation for screening all pregnant women for vitamin deficiency to improve maternal and fetal outcome. When Vitamin D deficiency is identified during pregnancy, daily doses of $2000 \mathrm{IU}$ vitamin $\mathrm{D}$ can be recommended.

In conclusion findings from present study suggest that maternal vitamin D supplementation in second trimester is significantly associated with better maternal and neonatal outcome.

Funding: No funding sources Conflict of interest: None declared

Ethical approval: The study was approved by the Institutional Ethics Committee

\section{REFERENCES}

1. Redman CW, Sacks GP, Sargent IL. Preeclampsia: an excessive maternal inflammatory response to pregnancy. Am J Obstet Gynecol. 1999;180:499506.
2. Grant WB. Role of vitamin D in up-regulating VEGF and reducing the risk of pre-eclampsia. Clin Sci (Lond). 2009;116(12):871.

3. Bodnar LM, Klebanoff MA, Gernand AD, Platt RW, Parks WT, Catov JM, et al. Maternal vitamin D status and spontaneous preterm birth by placental histology in the US Collaborative Perinatal Project. Am J Epidemiol. 2014;179:168-76.

4. Merewood A, Mehta SD, Chen TC, Bauchner H, Holick MF. Association between vitamin D deficiency and primary cesarean section. J ClinEndo crinol Metab. 2009;94(3):940-5.

5. Rochat MK, Ege MJ, Plabst D, Steinle J, Bitter S, Braun-Fahrl C, et al. Maternal vitamin D intake during pregnancy increases gene expression of ILT3 and ILT4 in cord blood. Clinical \& Experimental Allergy. 2010;40:786-94.

6. Scholl TO, Chen X. Vitamin D intake during pregnancy:association with maternal characteristics and infant birth weight. Early Hum Dev. 200985(4):231-4.

7. Sabour H, Hossein-Nezhad A, Maghbooli Z,Madani F, Mir E, Larijani B. Relationship between pregnancy outcomes and maternal vitamin $\mathrm{D}$ and calcium intake:A cross-sectional study. Gynecol Endocrinol. 2006;22;585-9.

Cite this article as: Singh N, Kumar D, Pandey K, Gupta N, Balyan R, Chandanan A. Study of vitamin $\mathrm{d}$ deficiency and supplementation in pre-eclamptic toxemia \& its feto-maternal outcome. Int J Reprod Contracept Obstet Gynecol 2015;4:1766-70. 